\title{
Resilience Ecotourism in Papua Amid Covid 19 Pandemic
}

\author{
Liliana Dewi \\ Tourism Department, Faculty of Economy and Business \\ National University \\ Corresponding Author: lilidewi.ana@gmail.com
}

\section{ARTICLE INFO}

Received

13 July 2020

Accepted

31 August 2020

Available online

30 September 2020

\begin{abstract}
Tourism destination is facing numerous crises caused by climate change, natural disaster, economic recession, instability political, internal turmoil and terrorism. These crises affect inbound tourism flows and consequently the tourism industry. New crisis as we know Covid 19 pandemic affecting many sectors, the most affected is the tourism industry. Purpose of this research was (1) to determine mitigation strategies of Ministry of Tourism and Creative Economy amid Covid 19 pandemic, (2) to learn the adaptation strategy of community ecotourism to survive amid Covid 19 pandemic and (3) to analyze the implication of Covid 19 epidemic on ecotourism destination resilience in Papua. The research was qualitative research with descriptive explanation, and data collections used interview, documentation, literature study. SWOT analysis method to analyze strength, weakness, opportunity and threat of resilience ecotourism in Papua. The procedure of data analysis techniques in this research used (1) data reduction, (2) presentation data, (3) conclusions. The result of this study showed there were three adaptation strategies (1) physically (2) economically, and (3) social. Covid 19 pandemic gives big implicated to the economic sector, social and culture sectors on ecotourism destination resilience. Cancellations of guest booking and travelling restriction impact on community ecotourism lifecycle. Meanwhile, other industries such as geography, demography, natural resources, politic and security were not implicated by Covid 19 pandemic.
\end{abstract}

Keywords: ecotourism, resilience, Papua, Covid 19

\section{INTRODUCTION}

\section{Background}

Covid 19 pandemic makes the world facing an unprecendeted global health emergency with an unparalleled http://ojs.unud.ac.id/index.php/eot impact on societies and livelihood; one of them is a travel and tourism the most affected by this crisis. Based on UNWTO World Tourism Barometer report impact of Covid 19 pandemic has caused a $20 \%$ decreasing in international tourist arrivals 
during the first quarter of 2020 and forecast could lead to an annual decline of between $60 \%$ and $80 \%$ compare to 2019 .

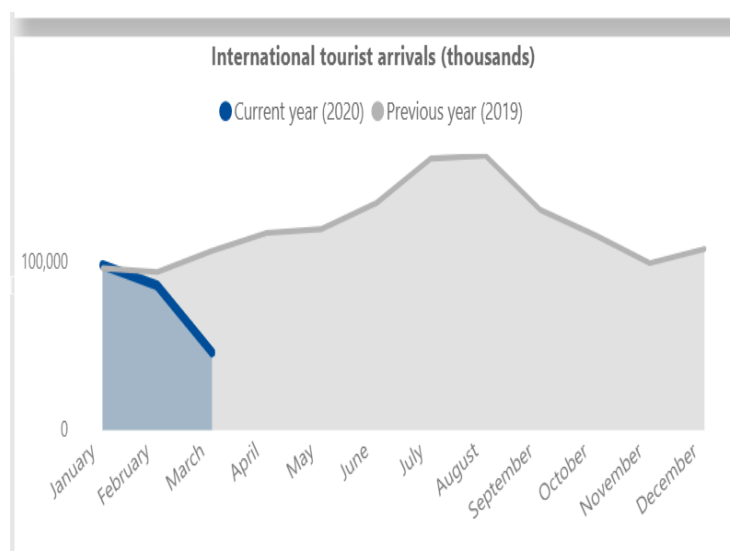

Figure 1. International Tourist Arrivals

Source: UNWTO, 2020

Figure 1 showed data that following the lockdown in many countries, travel restrictions and the closure of airports and national borders impact on decreasing $57 \%$ number of arrivals in March 2020 compared to international tourist arrivals in the previous year, 2019. This data means lots of the amount of global tourist arrivals decline, loss in revenue and tourism jobs atrisk situation.

Covid 19 pandemic was first confirmed to have spread to Indonesia on March 2, 2020. Since that day, the epidemic had spread to all 34 provinces in Indonesia. Prevention Covid 19 pandemic getting more wide-spread, large scale social restriction is an option to be implemented in Indonesia. Pandemic gave the tourism sector the hardest time to recover, thorugh The Ministry of Tourism and Creative http://ojs.unud.ac.id/index.php/eot
Economy of Indoensia reveal data number of international visitors to Indonesia were decline comparing to January until March 2019. Data showed in figure 2.

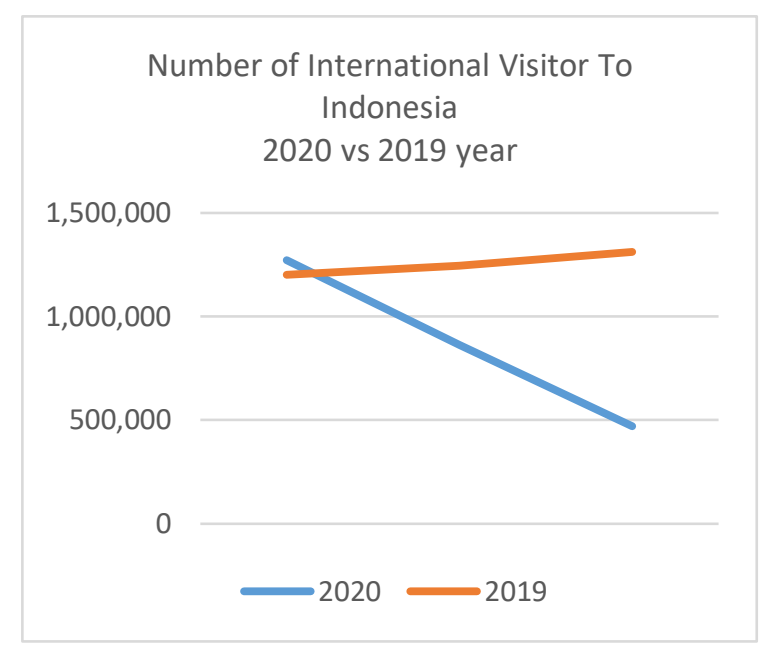

Figure 2. Number of International Visitor to Indonesia.

Source: The Ministry of Tourism and Creative Economy, 2020

Data on figure 2 from Indonesia Ministry of Tourism and Creative Economy explain total internationalvisitor from 26 main gates in Indonesia such as Ngurah Rai - Bali airport, Soekarno Hatta - Banten airport, Juanda-East Java airport, Kualanamu-North Sumatra sirport, Husein Sastranegara-West Java airport, Adi Sucipto-Yogyakarta airport, Bil-NTB airport, Sam Ratulangi-North Sulawesi, Minagkabau-West Sumatra airport, S. Syarif Kasim II-Riau airport, S. Iskandar Muda-Aceh airport, Supadio-West Kalimantan airport, Sultan M. Badaruddin II-South Sumatra airport, Batam-Riau e-ISSN: 2407-392X. p-ISSN: 2541-0857 
Island port and airport, Tanjung Uban-Riau Island port, Tanjung Pinang-Riau Island port, Tanjung Balai Karimun-Riau Island port, Tanjung Benoa-Bali port, JayapuraPapua terminal, Atambua-NTB terminal, Entikong-West Kalimantan terminal, ArukWest Kalimantan port, Nanga Badau-West Kalimantan port were 1,272,083 million international visitor on January 2020; 863,960 international visitor on February 2020; and 470,898 international visitor on March 2020 have been calculated.

Meanwhile, data on 2019 start from January were 1,201,735 and February 1,243,996; March 1,311,911 international visitors. This means that during pandemic Covid 19 and Social Distancing Restriction affected on number of interntional visitors slowly decrease every month start January untuk March 2020 comparing with data number of international visitors on 2019 show increasing numbers before pandemic Covid 19.

Based on data from (Travel, 2020) some of tourist attractions on Java Island, Bali Island, Sumatra Island, Kalimantan Island, Sulawesi Island, East Nusa Tenggara and other destination were closed. The impact of the spread of the Covid 19 felt by the hotel, restaurant, airline, entrepreneur who had massive share and investment value. Therefore, The Ministry of Tourism and Creative Economy take mitigation action. First, the social http://ojs.unud.ac.id/index.php/eot protection program for workers in the tourism sector. Second, reallocated the existing budget. Third, preparation of economic stimulus for business in tourism and creative economy sectors. Fourth, online training such as financial planning, English course, upskill and reskilling the human resources competencies in spa business. Fith, \#BanggabuatanIndonesia, and \#BeliKreatifLokal campaign to encourage people contribution helping each other to local products.

Indonesia Ministry of Tourism and Creative Economy predicts ecotourism product will attract tourists after the pandemic. The pandemic has changed the activities, behaviour of tourist. The tourism standard of health, safety, and clean protocols become new trends. Nature-based tourism activities and outdoor activities and outdoor activities will be a quick rebound because ecotourism is niche tourism. Therefore, ecotourism might become a new trend. The objective of this research is studying:

1) How mitigation strategies of the Ministry of Tourism and Creative Economy amid Covid 19 pandemic.

2) How adaptation strategy of community ecotourism amid Covid 19 pandemic.

3) How the Covid 19 pandemic implication on ecotourism destination resilience in Papua. 


\section{LITERATURE REVIEW}

Ecotourism is a type of tourism program that simple adopted by traditional communities. Based on (Wiranatha, 2015), ecotourism is an alternative form of tourism activity that recently adopted by the expertise and local communities to bring benefit for the local economy and to preserve the nature conservation

Ecotourism encourages local residents to use their culture in the natural conservation of their surroundings, contemporary forms an attraction for tourist. (Sitorus, 2017) explained the objective of ecotourism activities is to learn, to appreciate, and to preserve nature and to enhance the income of local communities.

Ecotourism consist of interacting agents including visitors, entrepreneurs and local communities, continually learn and adapt to external changes to find the best fit with the environment, and connect social, ecological, and economic subsystems through reliable feedback mechanism (Nabin, 2013). Local communities in ecotourism activities become an essential role in the process of implementation of ecotourism. Also, the government and entrepreneur acting as a catalyst or stimulus and a vital role in the development to increase the participation in ecotourism activities (Singgalen, 2019).
(Razak, 2017) define there are several components why ecotourism activities can be a new trend: (1) education level motivate ecotourism demand. Higherlevel education tends to have a connection to ecotourism activity request; (2) segmentation ecotourism from young, elderly healthy individuals. Ecotourism is niche tourism; (3) female roles determine ecotourism destinations; (4) holiday pattern changes; (5) quality service; (6) communication and information technology; (7) travel options; (8) individual security, safety, hygiene; (9) increased social and environmental concerns; (10) globalization of the economy.

Ecotourism should be based on the indigenous community given fact that society has better knowledge of their natural potentials, culture, culinary and handicrafts (Farid, 2020). Ecotourism program is one forms of community resilience that in a way, could support the efforts to extensive protection of forests and sea ecosystems (Farid, 2020).

Resilience is the ability to handle a natural disaster, social politic conflict, policy, knowledge to adapted with climate change, ability to manage ecosystem sustainability. Building community resilience is to reorganize the social life and environment that is resilient to various shocks. 
Resilience concept needs to integrate with the framework of empowerment and sustainability of community livelihood (Mahmudi, 2020). Resilience defined as the capacity of a social-ecological system to absord disturbance and reorganize while changing to retain mostly still the same function, structure, identity and feedbacks (Nabin, 2013). Resilience in the social-ecological system connected with diversity, innovation, the capacity to handle the disturbance and self-organization to respond to the changing environment.

Since WHO proclaim issue of Covid 19 pandemic, it has affected to ecotourism industry in Papua, travel and homestay booked was cancelled, zero tourism activities, the loss of jobs has posed financial problems for tourist guides. Local communities play a substantial role in ecotourism area, perspectives on sustainable development and environmental protection issue are vital for effective management (Jamaliah, 2017).

\section{METHOD}

During Covid 19 pandemic, and Social Distancing Restriction impacted on how this research was conduct. The researcher tried to do the research used a qualitative method with a descriptive explanation. Data collections include http://ojs.unud.ac.id/index.php/eot literature study, website and webinar. The procedure of data analysis techniques in this research was (1) data reduction, (2) presentation data, (3) conclusions. The informant involved in this research is Leader of Perkumpulan Penggerak Usaha dan Penghidupan masyarakat Asli Raja Ampat (Perjampat) Association, Manager of Trek-Papua Tours.

The study of the intended document is the searching of information through the internet to sharpen the analysis. This study focuses on three adaptation strategies: (1) physically adaptation strategy, economically adaptation strategy, and (3) social adaptation strategy.

In the early stages, researcher searching information about issues of pandemic Covid 19 impacted tourism industry, joined webinar held by UNWTO talked about impact of Covid 19 and a glimpse of hope for tourism industry, webinar workshop solution synergy of sustainability tourism amid pandemic Covid 19, rural tourism during epidemic Covid 19, EcoNusa TV.

Furthermore, searching article journal about ecotourism and resilience, data literature from UNWTO and Ministry of Tourism and Creative Economy about numbers of international tourist arrivals and names of the foreign visitor to Indonesia, mitigation action of Ministry of Tourism and Creative Economy. The researcher 
traced information through website, interview, and online news to ensure real condition.

\section{RESULT AND DISCUSSION}

\section{Mitigation Impact of Covid 19 Pandemic to Tourism Industry in Indonesia}

Indonesia Ministry of Tourism and Creative Economy has predicted that the decrease in international tourists visits Indonesia as the impact of epidemic Covid 19. Data show in table 1.

Table 1.

Number of International Visitor to Indonesia on January-March, 2019-2020

\begin{tabular}{llll}
\hline Main Gate & $\mathbf{2 0 1 9}$ & $\mathbf{2 0 2 0}$ & Percentage \\
\hline Ngurah Rai & $\begin{array}{l}1,329, \\
\text { 681 }\end{array}$ & $\begin{array}{l}\text { 1,040,92 } \\
\text { Soekarno- }\end{array}$ & $-21,72$ \\
Hatta & 785,30 & 357,116 & $-38,99$ \\
\hline Juanda & 51,678 & 34,521 & $-33,20$ \\
\hline Kualanamu & 59,197 & 41,066 & $-30,63$ \\
\hline Husein & 43,993 & 30,270 & $-31,19$ \\
Sastranegara & & & \\
\hline Adi Sucipto & 28,209 & 18,633 & $-33,95$ \\
\hline BIL & 9,284 & 11,821 & 27,33 \\
\hline $\begin{array}{l}\text { Sam } \\
\text { Ratulangi }\end{array}$ & 32,971 & 14,004 & $-57,53$ \\
\hline Minangkabau & 15,868 & 10,874 & $-31,47$ \\
\hline $\begin{array}{l}\text { S. Syarif } \\
\text { Kasim II }\end{array}$ & 8,510 & 6,787 & $-20,25$ \\
\hline S. Iskandar & 5,549 & 10,329 & 86,14 \\
Muda & & & $-24,19$ \\
\hline Ahmad Yani & 6,494 & 4,923 & $-33,02$ \\
\hline Supadio & 6,553 & 4,389 & $-14,03$ \\
\hline $\begin{array}{l}\text { Sultan } \\
\text { Hasanuddin }\end{array}$ & 4,155 & 3,572 & $-43,00$ \\
\hline $\begin{array}{l}\text { Sultan M. } \\
\text { Badaruddin II }\end{array}$ & 4,030 & 2,297 & \\
\hline Batam & 466,12 & 295,572 & $-36,59$ \\
\hline & 4 & & \\
\hline
\end{tabular}

\begin{tabular}{llll}
\hline Tj, Uban & $\begin{array}{l}151,15 \\
1\end{array}$ & 63,922 & $-57,71$ \\
\hline Tj. Pinang & 38,222 & 18,246 & $-52,26$ \\
\hline $\begin{array}{l}\text { Tj. Balai } \\
\text { Karimun }\end{array}$ & 30,842 & 21,523 & $-30,22$ \\
\hline Tj. Benoa & 12,914 & 8,768 & $-32,10$ \\
\hline Tj. Mas & 8,973 & 3,991 & $-55,52$ \\
\hline Jayapura & 12,178 & 5,670 & $-53,44$ \\
\hline Atambua & 20,549 & 23,379 & 13,77 \\
\hline Entikong & 6,087 & 4,679 & $-23,13$ \\
\hline Aruk & 4,964 & 4,297 & $-13,44$ \\
\hline Nanga Badau & 3,500 & 1,923 & $-45,06$ \\
\hline Total Visit & 2,946, & $2,043,50$ & $-30,66$ \\
\hline
\end{tabular}

Sources: Indonesia Minstry of Tourism and Creative Economy, 2020

Cumulatively, data from January until March showed in 2019 were 2,946,983 visitors, meanwhile the number of international visitors in January until March 2020 was 2,043,500 visitors. A total visit means there $-30,66$ percentage number of foreign visitors decreased. There 23 main gates were a decline in the sum of international visitors. At the same time there three main gates such as BIL or International Airport Lombok, S. Iskandar Muda airport, and Atambua airport showed the increasing number of international visitors.

Simultaneously with travelling restriction, there is a list of closed tourism attraction in regards to Covid 19 pandemic. Data shown in table 2. 
Table 2.

List of closed tourism attraction in regards to Covid 19

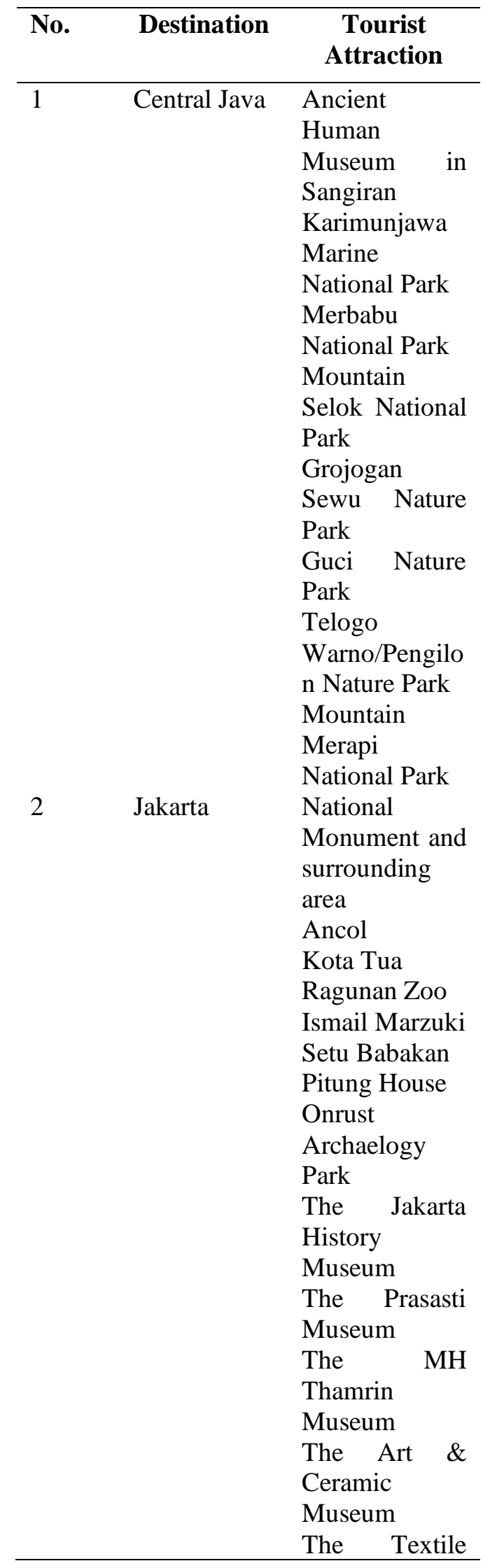

Museum

The Puppet

Museum

The Maritime

Museum

The Joang 45

Museum

MACAN

Museum

Mandiri

Museum

The Youth

Pledge

Museum

Museum if

National

Awakening

The National

Museum

The National

Library

Seribu

Archipelago

National Park

Muara Angke

Wildlife

Reserve

Rambut Island

Wildlife

Reserve

Pavilion of

DKI at TMII

Jakarta

Planetarium

Dance

Laboratory and

Karawitan,

Condet

Cipir Island

Kelor Island

Benyamin

Suaeb Park

Puppet Show

Bharata Miss

Tjitjih

Jakarta

Training Art

Building

Basoeki

Abdullah

Museum

Formulation of

The

Proclamation

Manuscript 


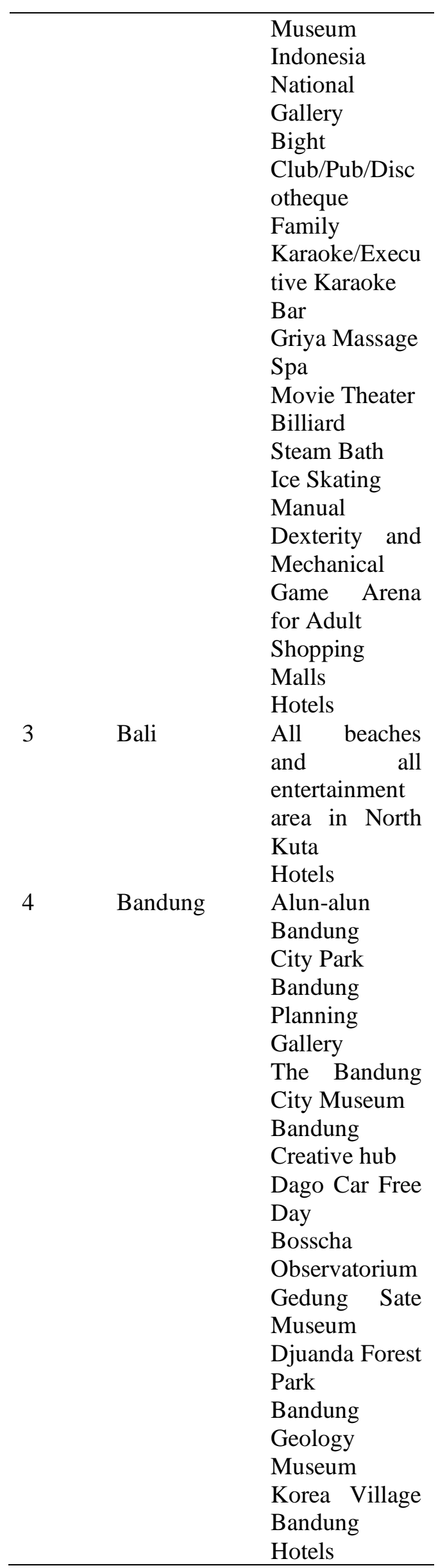

http://ojs.unud.ac.id/index.php/eot

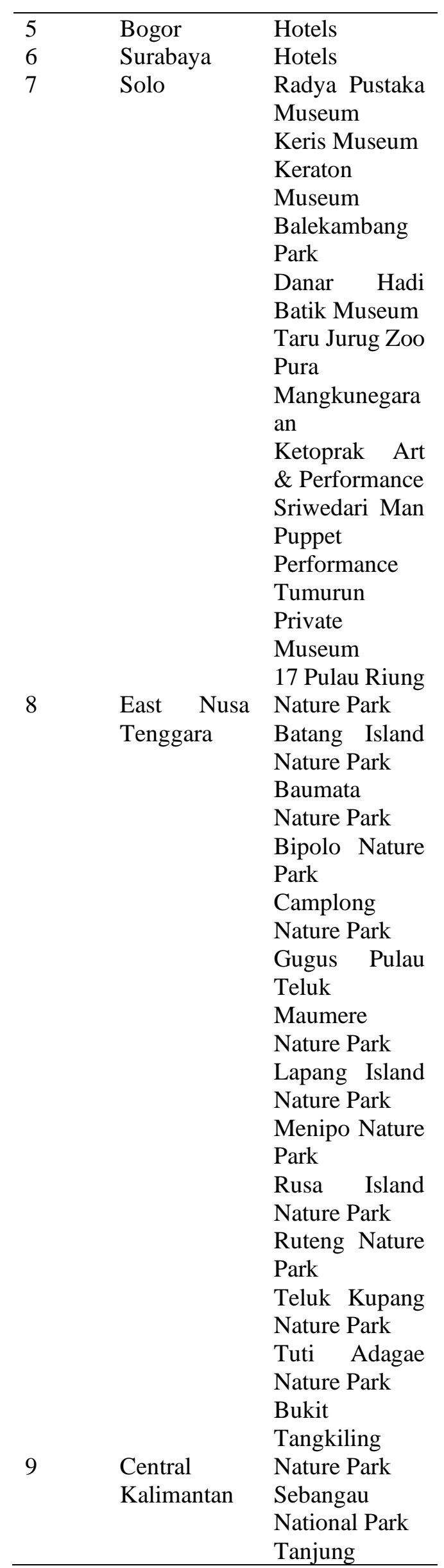




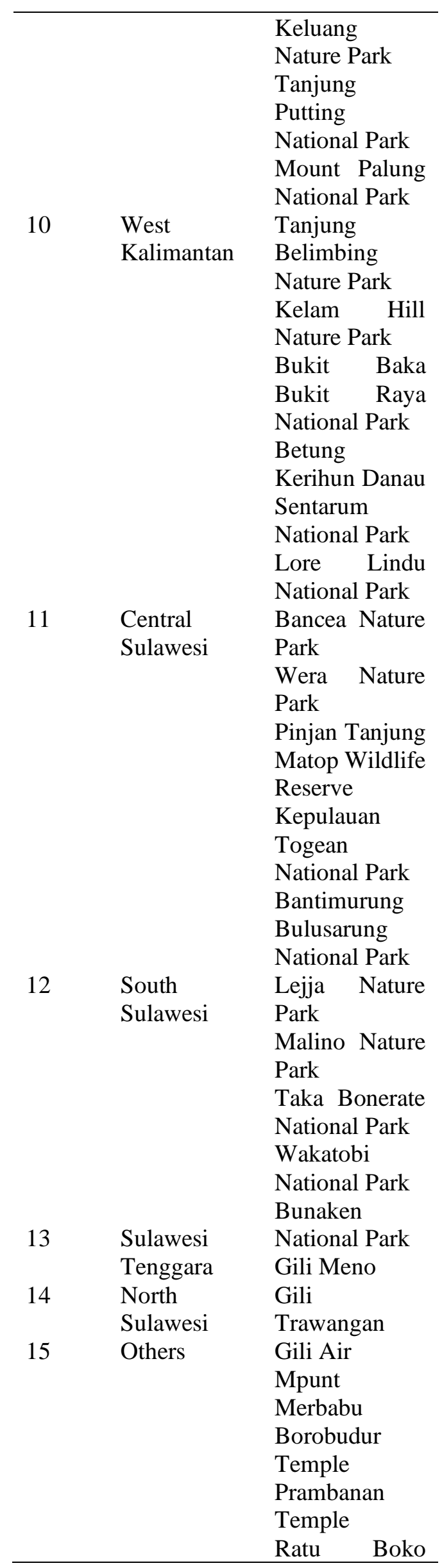

http://ojs.unud.ac.id/index.php/eot

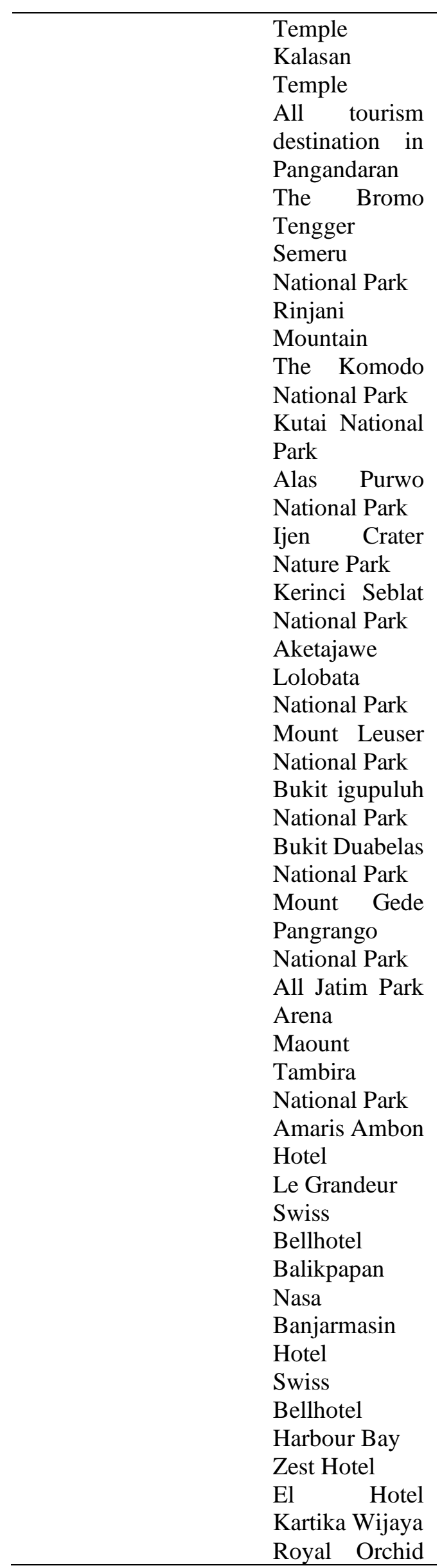




\begin{tabular}{ll}
\hline Batu \\
Amaris \\
Pettarani \\
Makasar \\
M. Bahalap \\
Palangkaraya \\
Hotel Kienne \\
Louis \\
Pandanaran \\
Semarang \\
Hotel Kienne \\
Louis Kisang Lima \\
Simparone \\
Maxone \\
Sukabumi \\
Hotel \\
Santika Ice BD \\
Hotel \\
Benteng \\
V'redeburg \\
Yogyakarta \\
Museum Kriti \\
Balai \\
Museum \\
Temple \\
(Pawom \\
Mendut, \\
Sambisari, \\
Sari, Barong, \\
Banyunibo, \\
Ijo, Gebang, \\
Keulan, Dieng, \\
Muarajambi, \\
Bumiayu, \\
Benteng \\
Marlborough, \\
Bung Karno's \\
Exile) \\
Batang Gadis \\
National Park \\
South Bukit \\
Barisan \\
National Park \\
Ujung Kulon \\
National Park \\
\hline \\
\hline If Toism
\end{tabular}

Sources: Indonesia Minstry of Tourism and Creative

Data from table 2 explained there more than 14 destinations in Indonesia with tourism attraction such as museums, shopping malls, national parks, hotels, temples, nature park, art \& performances, spa, and movie theatres were closed.

Indonesia Government, through the Ministry of Tourism and Creative Economy, takes mitigation action amid pandemic Covid 19 with First, social protection program for workers in the tourism sectors, distribute cloth masks. Second, reallocated the existing budget. Third, preparation of economic stimulus for business in tourism and creative economy sectors. The charitable donation will give to 44,925 art and creative sector's employees. Fourth, online training on improvement room attendant competencies, financial planning, English course, upskill and reskilling the human resources competencies in the spa business, increasing the capacity of MICE industry professional competencies.

Fifth, \#BanggaBuatanIndonesia and \#BeliKreatifLokal campaign to encourage people contribution helping each other to local products. Sixth, evaluation and rearrangement of ecotourism travel pattern have adjusted with the New Normal condition. Focusing on ecotourism and wellness tourism would be supported. In this case need a guarantee of cleanliness, health and safety preservation environmental quality of the area and involvement of local communitiesseventh, managing visitor management, e-ISSN: 2407-392X. p-ISSN: 2541-0857 
managing quota and dividing large groups into small groups during tourism activities. Adaptation strategy for New Normal Cleanliness, Health, and Safety (CHS) program associated in Indonesia tourism destination. The readiness of new standard tourism destination and community disciplines of Hygiene, Healthy and Clean protocol. Bali, Yogyakarta and Riau Island would become three priorities tourism destination were CHS program applied, followed by Labuan Bajo, Lombok, Banyuwangi, 5 priorities destinations and next to all tourism destination in Indonesia. There are main essential factors such as cleanliness in the room, public space with disinfectant, availability handwashing facilities and soap, clean trash net have associated.

Ministry of Tourism and Creative Economy maintains the existence of Indonesia Tourism in East Asia market, such as Japan, South Korea, Chinese, Taipei by organized through webinar series with more than 100 tourism industry practitioners from each organization.

Visual artists did exhibition from a home campaign organized by the Ministry of Tourism and Creative Economy, was a substitute for showrooms which have been the mainstay for displaying their works. AADC program for Accept, Adapt, Digital, and Creative Collaboration program was an adaptation strategy for Micro, Small, Medium Entrepreneurs (MSMEs) sectors. Ministry of Tourism and Creative Economy has applied several mitigation actions to the tourism industry, workers, entrepreneur during and after the pandemic. Adaptation strategy of the CHS program also was used for New Normal Indonesia tourism destination.

\section{Ecotourism in Papua}

Nature is still genuine, unique and unique culture, a particular interest of maritime, world heritage site Lorentz National Park, Teluk Cendrawasih National Park, Wasur National Park, Transfly Landscape \& Ecoregion, Abun in West Papua turtle conservation, Asmat. All these potentials are still pure to be a tourist attraction. One of the iconic tourist attractions in Papua is Raja Ampat, has preservation coral reef at Misool Ecoresort; Kayak conservation.

This conservation $100 \%$ income from tourism activities went to local communities and conservation purpose; Marine Wildlife Reserved preserved the sustainability of biodiversity in the islands; Raja Ampat Research \& Conservation Center; Green Turtle Research. 
Adaptation Strategy Scotourism in Papua Amid Pandemic Covid 19

The similar stories also happen in Papua; all tourists scheduled cancelled. Homestay, all of a sudden, has no occupation, no activitiy, no income. They have impacted to livelihood local communities. Based on information from the coordinator of Raja Ampat Association of Business Players and Natice People's Livelihood (Perjampat), the pandemic situation had encouraged local communities to move on the other way to survive.

Methods of local communities in adaptation strategy amid pandemic in Papua used different ways, such as sustaining the environment, protecting sea surrounding tourism attraction areas from illegally catching fisher that could be damaged environment.

The pandemic force local communities back to the previous livelihood activities, such as hunting wild boar, planting, selling yellow rice and wild boar to market, selling coffee, coffee beans, sage, do online business. Meanwhile, the Perjampat activities were made new trekking paths, identified wildlife along the original trekking path as new ecotourism offers, updating websites, fixing 2021 trips planning, build new facilities such as bungalow, homestay and renovation homestay.

\section{Obstacles Implementation Adaptation Strategy}

Lack of coordination and cooperation between government and communities makes different understanding, fear to be suspected Covid 19 so communities did not tell the truth to medical personnel when going to the hospital. Fast infected various gender, ages; vaccination still on progress research. Data were collected for ecotourism practitioners by the government, but support has not received yet by communities.

\section{The Implication of Pandemic Covid 19 on Ecotourism Resilience in Papua}

The implication of Covid 19 pandemic on ecotourism resilience in Papua in this research there were eight aspects of resistance will be explained.

First, Geography aspect. Geography for ecotourism was a vital tourism attraction; also a habitat for flora and fauna, and the environment becomes cleaner and fresh.

Second, Natural Resources aspect. Less of human activities on natural resources bring benefit to refresh, breath and regrow.

Third, Demography aspect was affected by the pandemic, and several populations decline $2 \%$ infected by Covid 19, $70 \%$ hospitalized. 
Fourth, Ideology aspect on ecotourism resilience had not been affected. Communities have a strong ideology of Pancasila.

Fifth, Politic aspect also not changed. Sixth, Economy aspect have big implicated of pandemic Covid 19 on ecotourism resilience. Loss of income, jobs makes ecotourism practitioners and communities must survive.

Seventh, Social Culture aspect on ecotourism resilience affected on the new habit on communities, practitioners started to be more concern about cleanliness, hygience, health, and safety; also need to be more sensitive on small group tourist, sanitation and hygiene of homestay and surrounding facilities, kitchen, food, more space on the room. Periodic clean and disinfectant ecotourism activities tools properties and mode of transportation.

Eighth, Safety aspect on ecotourism resilience need more protection fro illegal fishing, illegal action on ecotourism destination.

\section{Discussion}

This research focuses on three adaptation strategies forms, physical, economy, and society. Virus Covid 19 was a new disaster where hardest impacted to economic sectors, and common areas to all Indonesia region, even many countries. It is different from a natural disaster. It did not http://ojs.unud.ac.id/index.php/eot affect may destination, but Covid 19 changed lots of tourism destination in the economy and social sectors.

Tourist destination needs adaptation strategy on the physical area amid pandemic Covid 19 was local communities need to protect the environment from illegal industries or action. Therefore, local communities, tourism activities, tourism practitioners can be adapted from mitigation action to survive on the economy and social sectors.

Based on information from coordinator Perjampat, adaptation strategy of local communities during pandemic Covid 19 from the economy sector were encouraged communities to adapt again to the previous livelihood before tourism activities such as selling some product planting coffe and sage, fish, yellow rice, and wild boar to the traditional market and online business.

Meanwhile, from the social sector during pandemic there no ecotourism activities, local communities adapted with planting hydroponic, build homestay, coordinate with local government search new trekking at Kampung Dokay and Sosi, fishing and clean wash fish. At the same time, adaptation strategy on the physical sector of ecotourism was protecting sustainability environment, especially sea from illegal fishing, clearing area for preparation planting. 


\section{SWOT Analysis}

A swot analysis evaluates the interna strengths and weaknesses, and the external opportunities, and threats in an organization's environtment (Bonnici, 2015).

\section{Analysis of Internal Strenghts and Weaknesses}

Internal strength of Papua communities to resilient ecotourism during the pandemic is using natural resources from forest, sea, land by hunting wild boar, fishing skill, and planting skill made them able to endure.

Weaknesses of resilient ecotourism communities were less of coordination between government and communities, illegally fishing, lack of knowledge of Covid 19, tendency depends on tourism sectors as the main livelihood.

\section{Analysis of External Opportunities and Threats}

Opportunities to resilient ecosystem amid pandemic Covid 1919 refreshed, regrow, restructure environment. Ecotourism in Papua able to alive again with a new environment, as a result, ecotourism in Papua will have a new track, original path, new attraction to promote also to support conservation.

Communities also have new standard skills to live with cleanliness, hygiene, health, and safety. Have the opportunity and have time to strengthen institutional, fixing the website, differentiation new product to offer. Planning and mitigation risk management have time to create value-added.

The threat to resilient ecotourism in Papua was new changing protocal standard on running ecotourism business industry. There was the demand on cleanliness, hygiene, health, and safety of homestay and surrounding, kitchen products, facilities, restaurant, ecotourism attraction tools. Tendency stimulate tourism package needed to recover, demad on small group tourist, changing on tourist travelling behaviour and market share, demand more space on room, example tourist will not be willing to be in lots of people at the same room. There was high-cost forecasting.

\section{CONCLUSION}

There were seven mitigation programs strategies of Ministry Tourism and Creative Economy amid Covid 19 pandemic. Social protection for workers was the important, followed by reallocated budget, a stimulus for tourism business sector, live online training, campaign, evaluate and re-arrangement of ecotourism travel pattern and standard protocol, managing visitor management. 
Eight aspects of implication of Covid 19 pandemic on ecotourism destination resilience were geography, natural resources, demography, ideology, politic, economic, social culture, safety.

\section{ACKNOWLEDGEMENT}

National University funded this research. This research aims to contribute to tourism research industry during Covid 19 pandemic.

\section{REFERENCES}

Bonnici, T. S. (2015). SWOT Analysis. Wiley Encyclopedia of Management.

Farid, M. (2020, February 24). Econusa. Retrieved from https://www.econusa.id/en/ecostor y/ecotourism--nature-conservationand-indigenous-communityresilience-: https://www.econusa.id/en/ecostor y/ecotourism--nature-conservationand-indigenous-communityresilience-

Jamaliah, M. \&. (2017). Ecotourism Resilience To Climate Change in Dana Biosphere Reserve, Jordan. Journal of Susainable Tourism.

Mahmudi, A. (2020, May 11). Memahami Konsep Community Resilience \& Situasi Masalahnya. (Econusa, Interviewer)
Nabin, B. (2013). Evaluation and Resilience of Ecotourism in The Annapurna Conservation Area, Nepal. Environtmental COnservation, 84.

Razak, N. (2017). Ekowisata. Surabaya: IWEC Indonesia.

Singgalen, Y. A. (2019). Efforts to Achieve Environmental Sustainablity through Ecotourism. Journal of Indonesia TOurism and Development Studies, 111.

Sitorus, Y. L. (2017). Challenges in Developing Ecotourism in The Region of Lake Sentani Papua. EJournal Tourism, Vo. 4. No. 1, 2838. Retrieved from https://ojs.unud.ac.id/index.php/eot /article/view/30166/18482.

Travel, I. (2020, April 25). Indonesia Travel. Retrieved from Indonesia Travel: https://www.indonesia.travel/gb/en /news/list-of-closed-tourism-spotsin-regards-to-covid-19-outbreak.

Wiranatha, A. S. (2015). Sustainable Development Strategy For Ecotourism at Tangkahan, North Sumatera. E-Journal Tourism Vol. 2. No. 1, 1-8. Retrieved from https://ojs.unud.ac.id/index.php/eot/a rticle/view/19437/12877. 